\title{
A muscarinic view on $\mathbf{G q}$
}

\author{
Klaus Mohr • Christian Tränkle
}

Published online: 19 June 2013

(C) Springer-Verlag Berlin Heidelberg 2013

Quantification of agonist action can be challenging for the experimental pharmacologist, as the intensity of response to an agonist may vary depending on the effectiveness of signal transduction within the biological system. Signal amplification is addressed by terms such as "receptor reserve" and "spare receptors". Signal amplification can be quantified by operational models of agonism (Black and Leff 1983; Rajagopal et al. 2011; Kenakin et al. 2012; Kenakin and Christopoulos 2013). As a consequence of signal amplification, a partial agonist may-under experimental conditions of a receptor reserve-achieve the same maximum effect as the physiological full agonist. Furthermore, if the endogenous agonist already induces maximum activation of the system, super-agonism of an artificial compound, i.e., more-than-physiological receptor activation, is prone of being overlooked (Schrage et al. 2013). Therefore, with respect to preclinical pharmacology, primary and native cells as well as conventional isolated tissue preparations have high value. Worth mentioning, it was the isolated beating guinea pig atrium as a muscarinic $\mathrm{M}_{2}$ receptor model and alkane-bisammonio compounds such as W84 which first disclosed allosteric interactions at $\mathrm{G}$ protein-coupled receptors (Lüllmann et al. 1969). In addition, using the $\mathrm{M}_{2}$ receptor a physiological function of the allosteric vestibule has recently been proposed (Bock et al. 2012).

Odagaki et al. (this issue of the journal) employed the "Antibody-capture $\left[{ }^{35} \mathrm{~S}\right] \mathrm{GTP} \gamma \mathrm{S}$ scintillation proximity assay" (Porter et al. 2002; for review, see DeLapp 2004) to measure modulation of muscarinic $\mathrm{M}_{1}$ receptor signaling by a variety of orthosteric, allosteric, and bitopic

K. Mohr $(\bowtie) \cdot$ C. Tränkle

Pharmakologie und Toxikologie, Pharmazeutisches Institut, Universität Bonn, Gerhard-Domagk-Str. 3, 53121 Bonn, Germany

e-mail: k.mohr@uni-bonn.de orthosteric/allosteric ("dualsteric") compounds in membranes from rat cerebral cortex and hippocampus. There are five subtypes of muscarinic receptors. The odd-numbered receptors $M_{1}, M_{3}$, and $M_{5}$ preferentially couple to the Gqpathway, the even-numbered receptors $\mathrm{M}_{2}$ and $\mathrm{M}_{4}$ favor $\mathrm{Gi}$ (Wess et al. 2007). Levey et al. (1991) found that $\mathrm{M}_{1}, \mathrm{M}_{2}$, and $\mathrm{M}_{4}$ "accounted for the vast majority ... of muscarinic sites in rat brain". In the applied assay (Fig. 1), in order to focus on activation of the $\mathrm{M}_{1}$ subtype, selectivity for the Gqsignaling pathway is provided by an antibody which binds the G $\alpha q$ subunit of the Gq protein. Therefore, $\left[{ }^{35} \mathrm{~S}\right] \mathrm{GTP} \gamma \mathrm{S}$ bound to $\mathrm{M}_{2}$ and $\mathrm{M}_{4}$, which both prefer signaling into the Giroute, is not recognized by the assay. If $\mathrm{M}_{1}$ signaled into the Gi- (Offermanns et al. 1994) or the Gs-pathway (Burford and Nahorski 1996), the assay would not respond either.

The muscarinic acetylcholine receptor is archetypal for the allosteric modulation of $\mathrm{G}$ protein-coupled receptors (Lüllmann et al. 1969; Clark and Mitchelson 1976; Stockton et al. 1983; Jepsen et al. 1988; Tuček et al. 1990) and crystal structures of the inactive $\mathrm{M}_{2}$ and $\mathrm{M}_{3}$ receptor reveal a rather voluminous allosteric vestibule in the entrance of the ligand binding pocket (Haga et al. 2012; Kruse et al. 2012). Consequently, Odagaki et al. characterize the receptor interaction of various agonistic and inverse agonistic allosteric ligands as well as of $\mathrm{McN}-\mathrm{A} 343$ which is a bitopic allosteric/orthosteric agonist at the $\mathrm{M}_{2}$ subtype (Valant et al. 2008). Noteworthy, the intrinsic efficacy of some compounds was rather low compared with findings reported for cell lines, suggesting that physiological cells operate with comparably low signal amplification.

Taken together, Odagaki et al. provide almost encyclopedic information on $\mathrm{M}_{1}$ receptor-mediated Gq-signaling of dozens of muscarinic receptor ligands. Next, it would be interesting to learn more on how the ligands compare with regard to promiscuous and biased signaling. 
Ligands

$M_{1}$-receptor

Gq-protein

Rabbit

anti-G $\alpha$ q

Anti-rabbit ortho- allo- dual-steric

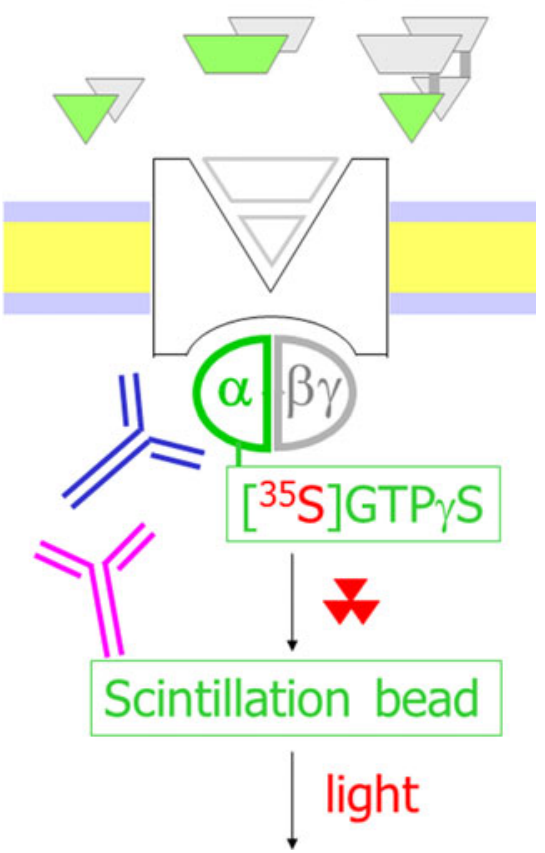

DeLapp NW (2004) The antibody-capture [(35)S]GTPgammaS scintillation proximity assay: a powerful emerging technique for analysis of GPCR pharmacology. Trends Pharmacol Sci 25:400-401

Haga K, Kruse AC, Asada H, Yurugi-Kobayashi T, Shiroishi M, Zhang C, Weis WI, Okada T, Kobilka BK, Haga T, Kobayashi T (2012) Structure of the human M2 muscarinic acetylcholine receptor bound to an antagonist. Nature 482:547-551

Jepsen K, Lüllmann H, Mohr K, Pfeffer J (1988) Allosteric stabilization of $3 \mathrm{H}-\mathrm{N}$-methylscopolamine binding in guinea-pig myocardium by an antidote against organophosphate intoxication. Pharmacol Toxicol 63:163-168

Kenakin T, Christopoulos A (2013) Signalling bias in new drug discovery: detection, quantification and therapeutic impact. Nat Rev Drug Discov 12:205-216, Review

Kenakin T, Watson C, Muniz-Medina V, Christopoulos A, Novick S (2012) A simple method for quantifying functional selectivity and agonist bias. ACS Chem Neurosci 3:193-203

Kruse AC, Hu J, Pan AC, Arlow DH, Rosenbaum DM, Rosemond E, Green HF, Liu T, Chae PS, Dror RO, Shaw DE, Weis WI, Wess J, Kobilka BK (2012) Structure and dynamics of the M3 muscarinic acetylcholine receptor. Nature 482:552-556

Levey AI, Kitt CA, Simonds WF, Price DL, Brann MR (1991) Identification and localization of muscarinic acetylcholine receptor proteins in brain with subtype-specific antibodies. J Neurosci 11:3218-3226

Lüllmann H, Ohnesorge FK, Schauwecker GC, Wassermann O (1969) Inhibition of the actions of carbachol and DFP on guinea pig isolated atria by alkane-bis-ammonium compounds. Eur J Pharmacol 6:241-247

Fig. $1 \mathrm{G} \alpha \mathrm{q}$-activation triggered by the $\mathrm{M}_{1}$ muscarinic acetylcholine receptor as measured with the "Antibody-capture $\left[{ }^{35} \mathrm{~S}\right] \mathrm{GTP} \gamma \mathrm{S}$ scintillation proximity assay" (for review, see DeLapp 2004) in the study of Odagaki et al. (this issue of the journal). Test compounds target either the orthosteric acetylcholine binding site located in the depth of the ligand binding pocket, or the allosteric site in the entrance of the binding pocket, or - in the case of dualsteric ligands - both sites simultaneously. Employed drugs include agonists (green) and inverse agonists (gray). Upon activation, $\mathrm{G}$ proteins recruit and irreversibly bind $\left[{ }^{35} \mathrm{~S}\right] \mathrm{GTP} \gamma \mathrm{S}$. The $\mathrm{G}$ protein of interest, i.e., Gq, is "fished" with a selective antibody (rabbit anti-G $\alpha q$ ). The latter antibody then mediates linkage with antibody-coated scintillation beads, thus allowing transformation of $\mathrm{G} \alpha \mathrm{q}$-bound $\left[{ }^{35} \mathrm{~S}\right] \mathrm{GTP} \gamma \mathrm{S}$ radiation into light flashes

\section{References}

Black JW, Leff P (1983) Operational models of pharmacological agonism. Proc R Soc Lond B Biol Sci 220:141-162

Bock A, Merten N, Schrage R, Dallanoce C, Bätz J, Klöckner J, Schmitz J, Matera C, Simon K, Kebig A, Peters L, Müller A, Schrobang-Ley J, Tränkle C, Hoffmann C, De Amici M, Holzgrabe U, Kostenis E (2012) Mohr K (2012) The allosteric vestibule of a seven transmembrane helical receptor controls Gprotein coupling. Nat Commun 3:1044. doi:10.1038/ncomms2028

Burford NT, Nahorski SR (1996) Muscarinic m1 receptor-stimulated adenylate cyclase activity in Chinese hamster ovary cells is mediated by $\mathrm{G}_{\mathrm{s}} \alpha$ and is not a consequence of phosphoinositidase $\mathrm{C}$ activation. Biochem J 315:883-888

Clark AL, Mitchelson F (1976) The inhibitory effect of gallamine on muscarinic receptors. Br J Pharmacol 58:323-331

Offermanns S, Wieland T, Homann D, Sandmann J, Bombien E, Spicher K, Schultz G, Jakobs KH (1994) Transfected muscarinic acetylcholine receptors selectively couple to Gi-type G proteins and Gq/11. Mol Pharmacol 45:890-898

Porter AC, Bymaster FP, DeLapp NW, Yamada M, Wess J, Hamilton SE, Nathanson NM, Felder CC (2002) M1 muscarinic receptor signaling in mouse hippocampus and cortex. Brain Res 944:82-89

Rajagopal S, Ahn S, Rominger DH, Gowen-MacDonald W, Lam CM, Dewire SM, Violin JD, Lefkowitz RJ (2011) Quantifying ligand bias at seven-transmembrane receptors. Mol Pharmacol 80:367777

Schrage R, Seemann W, Klöckner J, Dallanoce C, Racké K, Kostenis E, De Amici M, Holzgrabe U, Mohr K (2013) Agonists with supraphysiological efficacy at the muscarinic M2 ACh receptor. Br J Pharmacol 169:357-370

Stockton JM, Birdsall NJ, Burgen AS, Hulme EC (1983) Modification of the binding properties of muscarinic receptors by gallamine. Mol Pharmacol 23:551-557

Tuček S, Musílková J, Nedoma J, Proška J, Shelkovnikov S, Vorlíček J (1990) Positive cooperativity in the binding of alcuronium and Nmethylscopolamine to muscarinic acetylcholine receptors. Mol Pharmacol 38:674-680

Valant C, Gregory KJ, Hall NE, Scammells PJ, Lew MJ, Sexton PM, Christopoulos A (2008) A novel mechanism of G protein-coupled receptor functional selectivity. Muscarinic partial agonist McN-A343 as a bitopic orthosteric/allosteric ligand. J Biol Chem 283:29312-29321

Wess J, Eglen RM, Gautam D (2007) Muscarinic acetylcholine receptors: mutant mice provide new insights for drug development. Nat Rev Drug Discov 6:721-733 